\title{
SOME FACTORS OF CONTEMPORARY FINANCIAL BUSINESS OPERATIONS
}

\author{
Slobodan N. Bracanović ${ }^{1}$ \\ DOI: https://doi.org/10.31410/LIMEN.2020.207
}

\begin{abstract}
Contemporary forms of funding business entities are developed. Financial instruments of the capital market are built. Optimal financial strategies and tacticaloperational activities are a necessity. Financial managerial management and decision-making structures are of special significance. Financial capital is dominant in contemporary conditions. A credit-monetary policy is an important economic policy system.
\end{abstract}

Keywords: Finance, Market, Mechanisms, Capital, Policy, Strategies, Managers.

\section{PRIOR DETERMINANTS}

$\mathrm{I}$

n contemporary business, social and public entities, the financial function (7) must necessarily perceive, take care of and monitor the current forms of funding that ever more pronouncedly appear in the domestic conditions of doing business profitably.

The capital market is being attributed special significance in the modern epoch. (6) This is the point where capital offer and capital demand face and confront each other. Diverse forms of financial mechanisms and/or instruments are manifested. A larger number of actors also appear (such as, for example, the state, investors, issuers, etc.). The market continuously develops.

Furthermore, conceptually, the market organizer is established as a joint-stock company managing and performing activities in connection with the functioning of the regulated market. A regulated market means a multilateral system, which is both organized and managed by the market organizer and which enables and improves the integration of the interests and goals of "third parties" in the domain of the purchase and sale of financial instruments.

The basic jobs on a regulated market are diverse and differentiated: establishing a link between entities' (actors') aspirations in transactions through financial mechanisms and instruments; the collection (concentration), storage and disclosure of information about the offer, demand and quotation of and the market prices for financial instruments. Additional jobs are also diverse and differentiated: the improvement of the development and promotion of the capital market; the licensing and sale of market elements, encompassing the formation, licensing, sale and trade of financial instruments; the investor's education, and so forth.

The "market organizer" and a "regulated market" cannot perform the trade of financial instruments. Investment in the financial instruments issued by appropriate factors (the Republic of Serbia, the National Bank of Serbia, the units of local self-government, or certain foreign institutions) is, however, enabled.

1 Faculty of Economics in Priština, Kosovska Mitrovica 
An "investment company" (the "market maker") transacts through the purchase and sale of financial instruments (for its own account, using its own property and assets, in accordance with the prices it establishes on its own). It is continuously present on financial markets.

The "patron" implies the investment company performing the services of sponsorship connected with the offer and sale of financial instruments and a repurchase obligation. On the other hand, an "agent" is the investment company performing services in connection with the offer and sale of financial instruments and without a repurchase obligation.

"Clearing" includes the procedure of the establishment of the mutual obligations of both the seller and the buyer (financial instrumentarium) with the aim and for the purpose of exchanging financial instruments and funds. The "settlement of accounts" reflects in achieving transactions via the final transfer of financial instruments and monies between the seller and the buyer as well. $(3 ; 332-334)$.

A "multilateral merchant platform" signifies a multilateral system organized and managed by an "investment company" or the market organizer, the one which encourages the integral interests of "third parties" in the purchase and sale of financial instruments. There is also a "secondary market" for trading transactions with financial instruments based upon the buyerseller negotiation flow system. The business operations of a regulated market in domestic conditions can only be managed by the "stock exchange", i.e. the market organizer (authorized by a competent authority). The organizer of a multilateral merchant platform can be a "brokerdealer company" or the stock exchange. Furthermore, the stock exchange is obliged to organize the "listing" of securities (and at least yet another part, i.e. segment, of the regulated market for trading "operations" with owner's securities). It is about a managed, regulated and controlled (supervised), rather than spontaneous, chaotic and anarchic market as is the state of the matters on the strong economic-financial collapse in the USA $(2007 / 8)$. (3; 334).

\section{MODERN FORMS OF FUNDING BUSINESS ENTITIES}

Contemporary current (2) market forms and the forms of funding the enterprises that are not present in the domicile economic and systemic conditions are being developed, built and upgraded. The panoply of these relevant forms is broad, and it is simultaneously both rational and purposeful that certain forms of priority significance should also be crystallized.

Diagram 1. Some contemporary forms of funding business entities, i.e. enterprises:

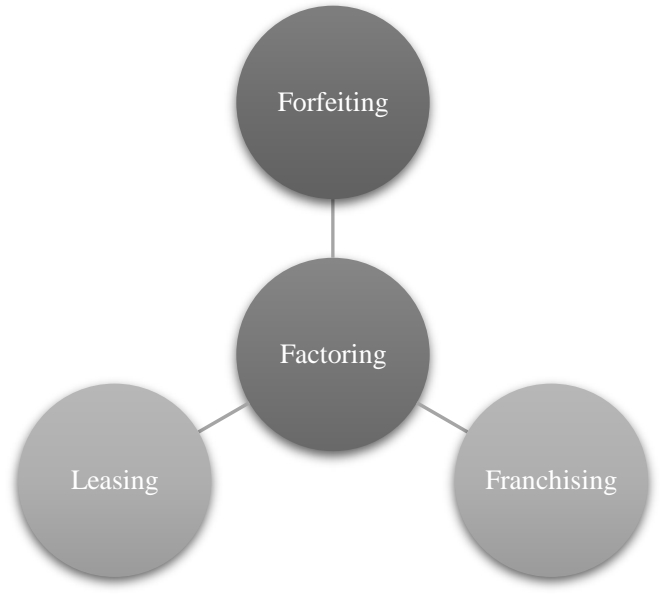

Source: Own research 
Leasing implies both an economic transaction and a legal transaction between two or more business entities that ensure the procurement of necessary business (basic and working) assets in a faster, dynamic, economic, and cost-effective manner through their contractual relationship. An enterprise (or an entrepreneur) is the lessee of the assets received from a lessor, who still remains the owner.

Factoring is a form of a loan placement and the "servicing" of the collection of receivables from buyers in the country. Business factors (enterprises) may assign and/or sell their own receivables from their buyers to a "factoring" firm at a discount (generating cash as well).

Forfeiting denotes a form of funding export loan arrangements, which is performed by selling an export receivable to a bank. It is about the sale of such receivables abroad. These receivables are of a long-term character. Capital turnover is also dynamized. The securities secondary market is also formed.

Franchising presupposes the sale of goods in a retail system/network to consumers based upon contractual and practical relationships between franchisors and franchisees. We may speak about manufacturing, transactional and (potentially) related franchising. Transactional (business, economic) franchising implies the sale of goods to end consumers. Apart from rights to the products of the franchisor, manufacturing (industrial) franchising also includes a right to the production of that product. $(3 ; 333)$.

Diagram 2. The differentiated modalities (types) of indicative financial instruments:

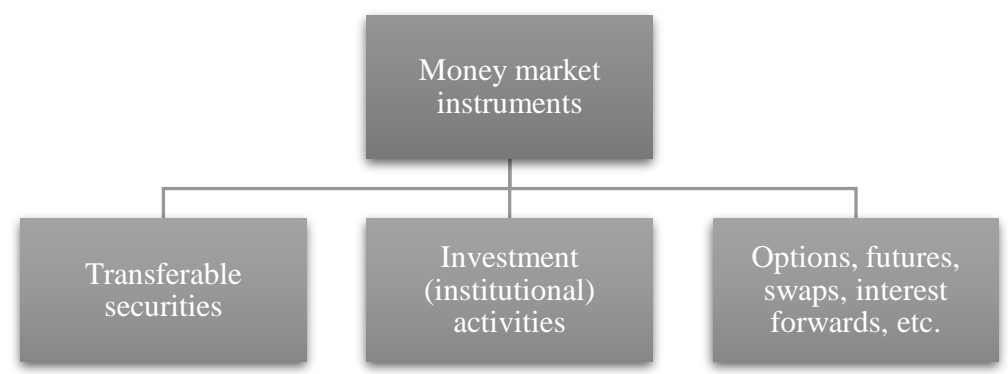

(Note: All the diagrams in the paper are the author's individual and independent creation.)

Source: Own research

To be more concrete, the money market instruments consist of the instrumentarium used to perform trading activities (transactions) on the money market (treasury bills and notes, and commercial papers and certificates of deposit, except for payment instruments).

There are options, futures, interest forwards and other derived financial instruments, which encompass securities, monetary units (currencies), interest rates, returns, financial indices and measures which are related to goods and which are possible to settle in cash (i.e. in value) or physically (i.e. in kind), loan risk transfer instruments, contracts (for differences), as well as other inflation elements (i.e. inflation rates), costs of transport, issued quotes, which further also relate to property, rights, obligations and so forth. There are broader financial instruments (not included in the previous concept) which are issued in connection with the sale of goods and/or services (a cheque, a bill, a written instruction (i.e. assignment), a bill of lading, a consignment note, or a warehouse warrant and so on). (3; 334-336). 
The capital market instruments (long-term financial instruments) imply instruments with a longer maturity period (i.e. a period exceeding one year). Long-term securities encompass a) the owner's securities (stocks and shares) and b) the debtor's securities (liabilities). They denote a right to the issuer's future return. Return from shares (a dividend) is not certain and the owner of a share does not have legal protection, either (unless such dividend is paid out by the issuer). Contrary to that, return from a bill (interest) is certain and the owner of such bill may request that the principal amount and/or interest should be paid out.

A share (of any type) gives the owner the right to control the operations of the enterprise, the right to a share in a potential profit, the right of "prior purchase" in the issuance of new shares, the right to the "residual" part of the liquidation estate of the enterprise and to a transfer of shares and so on. The (investor's return) capitalization rate expresses the temporal value of money and the riskiness of expected dividends.

When speaking about bonds (of the issuer type), the following bonds are possible to differentiate, namely state (public) bonds, the bonds of local and republic authorities, corporative bonds, mortgage bonds, and so forth. The return capitalization model is the method for valuing bonds. The model is based on discounting the monetary flows which the investor predicts he will achieve in the future based upon his ownership of a specific property. Market interest rates (inversely affecting prices) are given a role and they differ depending on a different term to maturity. State bonds are (especially) discount instruments realized as per prices lower than the nominal one. A discount (interest) rate is the return rate to maturity and represents an opportunity cost of capital, i.e. an internal rate of capital return. Future returns are reduced to the present, zero moment.

When making investment decisions, investors apply the "rating lists" of the issuer subjects, i.e. securities (published by specialized rating agencies), or the sectors for and departments of loan analysis in big investors. Securities of an investment character are higher-ranked corporate bonds, and securities of a speculative character are lower-ranked. $(3 ; 337-338)$ The objectivity of a rank is often a fiction as well.

Diagram 3. The main financial and developmental concepts, strategies and managerial structure

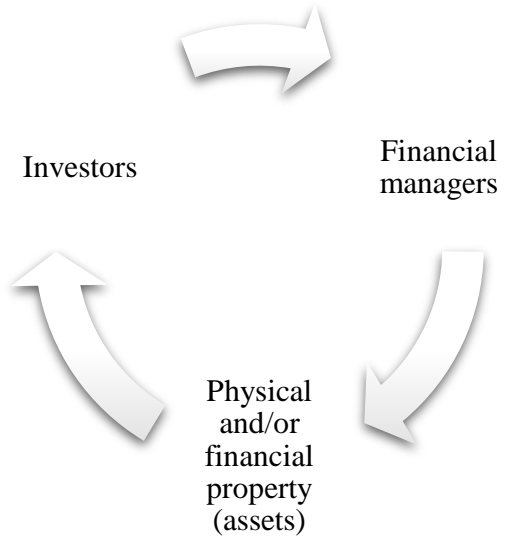

Source: Own research

The financial function is effectuated by primarily bearing in mind the fact of the timely rational funding of the economic growth and development $(5 ; 195-211)$ of business entities; the minimization of financial risks; the maximization (optimization) of the utilization of financial 
possibilities on the capital market; the adaptability and ability to react in the cases of monetary deformations, fluctuations (oscillations), disturbances, recessions, depressions and crises, the maintenance of the ability to valorize (payments) and creditworthiness (financial reliability), as well as the efficient and effective financial business operations; business reputation (i.e. rating), and so on. Apart from said, the important goals and tasks on the part of financial managers inside the financial target function in a business entity (i.e. an enterprise) are as follows: adherence to the provisions and rules of the science of finance and/or the financial profession; the legislative normative regulations in the domains of the management, directing and coordination of cash and other assets, net business (basic and working) assets, inventories, buyers and suppliers and investments, (uncollected, suspicious and disputable) receivables, and so on. Besides, it is necessary that financial visions, ideas and leading ideas ("guiding stars"), projections, concepts and longer- and long-term strategies, as well as the tactical-operational activities of a shorter and short term should be established with respect to realistic possibilities, as well as the requirements of other business functions (in the domain of work in progress, finished products, inventories, credit conditions, "sponsorship", distribution channels, the maintenance of the threshold and level of cost-effectiveness, the economical quality, tangible, intangible and combined instructions to employees and so on. It is also necessary that the external conditions of closer and/or more distanced environment and contemporary processes, procedures and/or techniques of transformation and restructuring (of funds, assets, securities, shares and stocks, the sale of a part of the enterprise or the division of the enterprise and the establishment of new ones; the purchase of such shares and stocks by the management, employees and groups; buying an enterprise by exchanging shares and stocks, and so on) should be perceived. $(3 ; 339-340)$.

Contemporary financial conditions are characterized by virtual, parallel and fictitious or, also, realistically nonexistent finance (funds). Financial and speculative "bubbles" and pyramidal structures deprived of any cover at all are formed. (1).

Financial markets require regulation and state (public) management, control and supervision. Otherwise, in conditions to the contrary, there will be an unavoidable fall in and collapse of financial markets, which objectively is the condition in the case of the mortgage and economicfinancial crisis generated in the USA (2007/2008), which overflowed into both western and other countries. (1).

\section{SOME MONETARY INDICATORS IN SERBIA}

Observing the structure of the sources of the assets of the banking entities in Serbia, it is possible to see the prevailing share, i.e. the formative share, of lent assets $(85.6 \%$ at the end of June 2020). In comparison with the very same period last year, and in relation to the previous month as well, the lent sources of assets have increased $1.6 \%$ and $0.3 \%$, respectively. There is a rational orientation towards the growth of the structural share of own assets in total assets. Other more favorable tendencies (such as the growth of bank deposits of various types) are being crystallized as well.

The foreign exchange indicators of the institution of the National Bank of Serbia are achieving more favorable trends (they are achieving the growth of the foreign exchange reserve and the foreign exchange savings in the retail sector as well).

The NBS has reached the reference interest rate at a certain level (1.25\% in June 2020$)$. The comparable trends are lower in the institutions of ECB $(0.00 \%)$ and FED $(0.00-0.25 \%)$. 
Certain inflationary trends have been achieved (1.6\% at the interannual level in June 2020 and a significant impact of the oil derivative price descending trend). Inflationary tendencies in the indicative territory of the EU are pronounced (being $0.8 \%$ at the annual level).

When speaking about the Belgrade Stock Exchange, securities (bonds and stocks and shares) trading has substantially been reduced (June 2020) in comparison with the identical period last year (by $82.4 \%$ ), which is partly also explained by the unfavorable conditions (caused by the epidemic).

To repeat once again, the special significance of state (issued) securities and investors (individual investors are the most pronounced bank factors) are indicative.

The economic-financial policy is undertaking measures (to mitigate the epidemic).

Table 1. The volumes of the movement of the foreign exchange reserves of the NBS and the foreign exchange savings (in million euros)

\begin{tabular}{|l|c|c|c|c|c|}
\hline Elements & 2001 & 2007 & 2013 & 2019. & Growth (\%) \\
\hline Reserves & 1,325 & 9,634 & 11,189 & 13,779 & 13.89 \\
\hline Savings & 330 & 4,903 & 8,118 & 10,801 & 34.06 \\
\hline
\end{tabular}

Source: Ministry of Finance of the Republic of Serbia (June 2020), Belgrade Public Finance Bulletin, pp. $12-14$

Note: According to the observed temporal semiannual interval (i.e. the period from January to June 2020), the foreign exchange reserves of the NBS are in the amount of 13,956 mill. euros, and the foreign exchange savings are 10,988 million euros.

Graph 1. The volume of the available foreign exchange funds on a long-term time horizon:

The Dynamics of the Movement of the Foreign Exchange Reserves of the NBS and the Foreign Exchange Savings

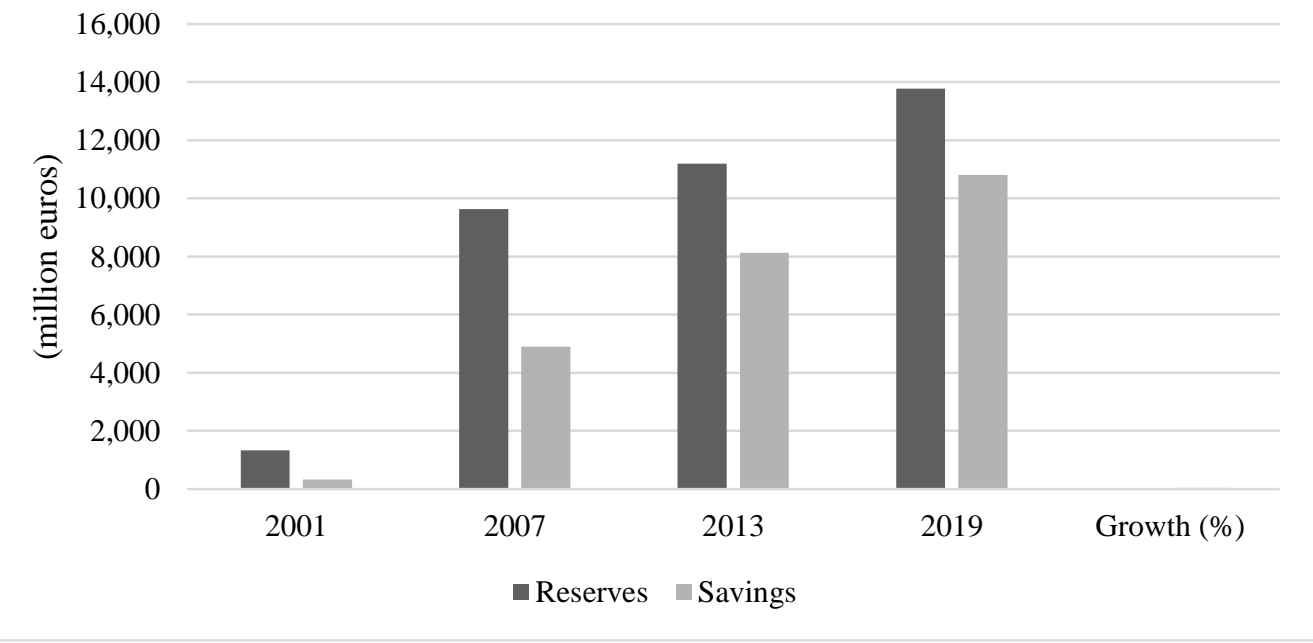

Table 2. The tendencies of the movement of the level of the reference interest rate of the NBS in a long-term period

\begin{tabular}{|l|c|c|c|c|}
\hline Elements & 2006 & 2013 & 2019 & Growth (\%) \\
\hline Interest rate & 14.00 & 9.50 & 2.25 & -13.15 \\
\hline
\end{tabular}

Note: The reference interest rate of the NBS is $1.25 \%$ in the semiannual period (from January to June 2020).

Source: Ibid, pp. $12-14$ 
Graph 2. The characteristic trend of the volume of the reference interest rate in a longer interval:

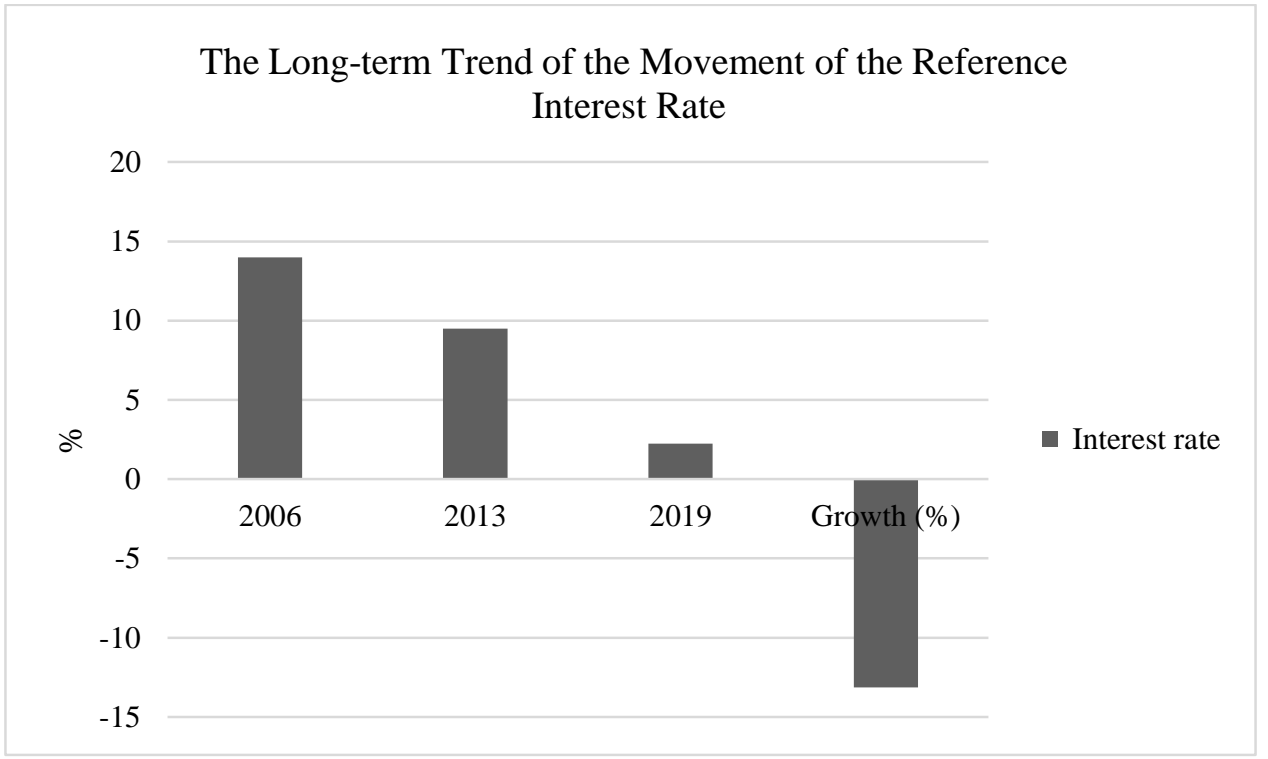

Table 3. The tendencies of the level of the foreign exchange rate, i.e. the ratio between the Euro Zone currency and the domicile currency:

\begin{tabular}{|l|c|c|c|c|c|}
\hline Elements & 2001 & 2007 & 2013 & 2019 & Growth (\%) \\
\hline Euro : Dinar & 59.71 & 79.24 & 111.61 & 117.59 & 3.84 \\
\hline Average & 60.69 & 79.96 & 113.11 & 117.85 & 3.75 \\
\hline
\end{tabular}

Note: In the semiannual period from January to June 2020, the value of the Euro Zone currency in relation to the domicile currency was 117.58, whereas the average level during this period was 117.59.

Source: Ibid, pp. $12-14$

Graph 3. The crystallized long-term statistical relations of the movement of the euro and the domestic currency:

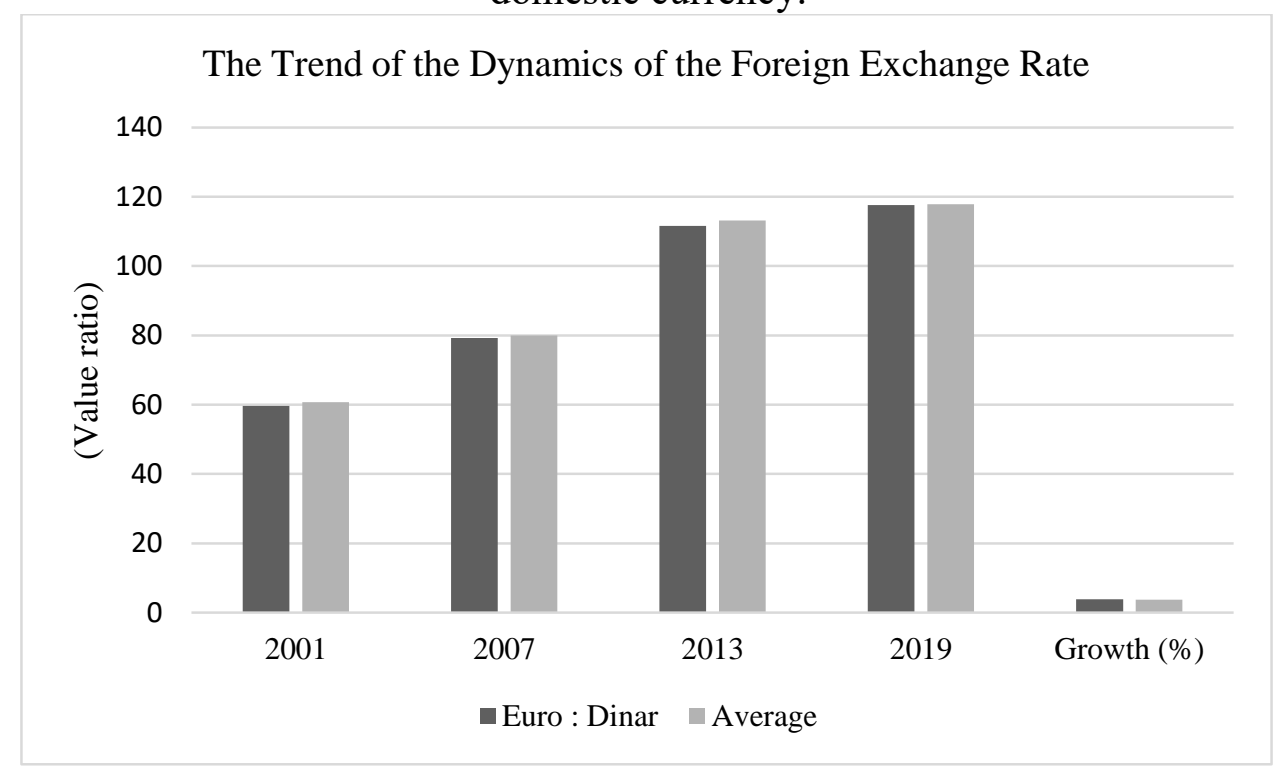




\section{CONCLUSION}

From the practical credit-monetary standpoint, foreign exchange sources $(50.6 \%$, the same being reduced by $1.8 \%$ in comparison with the period in June 2019) have a predominant share in the currency structure of the asset (capital) sources in Serbia. The increased level of the foreign exchange reserves of the NBS is sufficient to cover the money supply (M1, 147\%) and to cover more than the semiannual imports of goods and services. In comparison with the very same period last year, the foreign exchange rate has achieved a nominal appreciation and a real appreciation of $0.3 \%$ and $1.6 \%$, respectively. With the aim of amortizing the enormous current fluctuations, the NBS intervened on the interbank foreign exchange market by the net sale of foreign exchange (in a volume of 155 million euros during June). The total market capitalization is significant (the same being 479.7 billion dinars at the end of June, reduced by $3.2 \%$ in comparison with the identical period in the year 2019). The price for oil (of the Urals type) has been reduced (since the beginning of the year 2020, in comparison with the very same period in the year 2019 by $40.2 \%)$. (4; 8-10).

\section{REFERENCES}

Bulatović M. (2018), Nevidljivi lanci - Moć nepostojećeg novca, Laguna, Beograd;

Đurić Z. (2011), Menadžment porodičnog biznisa, Beogradska poslovna škola, Visoka škola strukovnih studija, Beograd;

Mašić B., Dželetović M (2015), Uvod u menadžment, Inovacioni centar Fakulteta bezbjednosti, Univerziteta u Beogradu, Akademska knjiga, Novi Sad, Beograd;

Ministarstvo finansija Republike Srbije (jun, 2020), Bilten javnih finansija, Beograd. str. 1214 ;

Rikalović G. (2002), Dugoročni ekonomski razvoj - Način stvaranja bogatstva; Ekonomski zbornik Srpske akademije nauka i umjetnosti, Knjiga, 12, Beograd, str.195-211;

Stojadinović D. (2006) Ekonomski kalendar, Akademska štampa, Beograd, Zemun;

Štiglic, E. Dž., (2016), Evro - Kako zajednička valuta ugrožava budućnost Evrope, Akademska knjiga, Novi Sad. 